\title{
IRRIGATION AND FERTILIZATION OF CHRYSOTHAMNUS NAUSEOSUS (ASTERACEAE) AFFECT THE ATTACK AND GALL GROWTH OF RHOPALOMYIA CHRYSOTHAMNI (CECIDOMYIIDAE)
}

\author{
G. Wilson Fernandes ${ }^{1, *}$, Peter W. Price ${ }^{2}$, Débora do Vale Santos ${ }^{1}$, Daniel Negreiros $^{1}$ \\ ${ }^{1}$ Ecologia Evolutiva e Biodiversidade/DGEE, CP 486, ICB/Universidade Federal de Minas \\ Gerais, 30161-970. Belo Horizonte, MG, Brazil. \\ 2 Department of Biological Sciences, Northern Arizona University, 86011-5640, Flagstaff, Arizona, \\ EUA. \\ *Corresponding author: gw.fernandes@gmail.com
}

\begin{abstract}
.
Environmental factors can affect the suitability of host plants for the survival and development of galling insects. The effect of nutrients and water availability on the development of galls induced by Rhopalomyia chrysothamni (Diptera: Cecidomyiidae) on Chrysothamnus nauseosus subsp. hololeucus (Asteraceae) was tested. The study was conducted in a xeric area with no signs of disturbances in Coconino National Forest, Arizona, USA. Individuals of C. nauseosus randomly selected underwent three treatments of water and nutrients availability. At the end of the growing season, the number of attacked plants, abundance and the development of galls in each treatment were evaluated. The differences in habitat quality simulated by the fertility and humidity conditions influenced both the number of attacked plants and the growth of galls. Plants with lower hydric-nutritional quality were more attacked by the galling insect. Otherwise, when both water and nutritional stresses were relieved plants developed galls with higher dry biomass and density. Therefore, this field experimental study indicates that while galling females attacked plants more in xeric environments, the galls grew larger in relatively more mesic conditions. The results showed a trade-off between the quantity and quality of galls of $\mathrm{R}$. chrysothamni depending on the nutritional quality of the host plants.
\end{abstract}

Key words: environmental stress; gall development; host plant quality; insect galls; resource availability.

\section{INTRODUCTION}

During the larval stage gall-inducing insects cannot move on the host plant, having evolved a unique way of draining resources of distant plant organs for their maintenance (e.g. Kirst \& Rapp 1974; Price et al. 1987; Larson \& Whitham 1991; Silva et al. 1996; Fernandes et al. 1999; Tooker \& Helms 2014). Probably, this evolutionary path led them to an extreme of the specialist-generalist gradient as they are extremely specific about the choice of the host (Mani 1964; Price et al. 1998; Carneiro et al. 2009). In general, adult females of galling insects oviposit in meristematic tissues of the host plant and induce gall development, where their offspring grow. The galls provide the larvae with high quality food and protection from the adverse external environment and natural enemies (Price et al. 1986, 1987; Fernandes \& Price 1991). The incapacity to move in order to explore the mosaic of nutrients of different qualities and degree of availability on the host plant were probably key factors in the evolution of the ability to divert plant resources and use them for its own development.

Galling insects may cause variable impacts on host plant performance depending on the drain strength and gall abundance (Fay et al. 1996; Gonçalves-Alvim et al. 1999, 2001; Fernandes et al. 2012; Xiang et al. 2020). But despite the efficiency of these herbivores in obtaining resources, the quality and amount of resources offered by the host plant play a crucial role in the choice made by females and subsequent development of their larvae (Price et al. 1990; Fernandes \& Price 1992; Araújo et al. 2003; Fonseca \& Fleck 2007; Santos et al. 2007; Miller \& Raman 2019; reviewed by Cornelissen et al. 2008).

The interactions of host plant quality and success of galling insects are influenced by the habitat (Fernandes \& Price 1988; Cuevas-Reyes et al. 2004; 2011). Several studies have indicated the existence of a greater richness and abundance of galling insects in xeric habitats as opposed to mesic habitats. 
The greatest success of galling insects in xeric habitats is conditioned by hydric-nutritional stress of the environment and the host plant (Fernandes \& Price 1988, 1992). Under conditions of nutrient deficiency, particularly phosphorus (Fernandes \& Price 1991), plants become more sclerophyllous with leathery leaves, which reduce the likelihood of abscission (Fernandes \& Price 1991; Gonçalves-Alvim \& Fernandes 2001; Fagundes et al. 2001). Besides that, they have higher concentration of tannins and other defense compounds which apparently protect galling insects against pathogens and predators (Fernandes \& Price 1988, 1992; Fernandes et al. 1994; Mithöfer \& Boland 2012; Hall et al. 2017). Thus, the host plant tissues in xeric environments become large nutritive reserves and even provide shelter and protection to the larvae of galling insects, indicating that soil fertility is of considerable importance in the relationship between environmental quality, richness and performance of galling insects (Fernandes \& Price 1991; Blanche \& Westoby 1995; Gonçalves-Alvim \& Fernandes 2001; Cuevas-Reyes et al. 2004, 2011).

Plants in fertilized soils grow better and larger. The additional nutrients can be diverted away from growth and reproduction and used to produce larger galls (e.g. Rossi \& Stiling 1998; Cuevas-Reyes et al. 2004). Therefore, there are good indications that both the distribution of galls per plant and growth of galls are related to the distinct hydric-nutritional status of plant communities and habitats. In this context, the present study aimed to evaluate the effect of increasing water and nutrient availability in the host plant Chrysothmanus nauseosus subsp. hololeucus (A. Gray) H. M. Hall \& Clem. (Asteraceae) on the oviposition by females of Rhopalomyia chrysotham$n i$ Felt (Diptera: Cecidomyiidae) and gall growth in the Sonoran Desert, USA. Galls of this cecidomyiid species are found in high abundance and are easily seen year-round, hence providing a good model for the study on the role of plant and habitat quality on insect gall numbers per plant and gall growth. In this study we tested the hypothesis that plants in habitats characterized by higher nutritional and water stresses have higher number of galls per plant and increased growth of galls.

\section{Materials ANd Methods}

\section{Study area and selected species}

The study was conducted in Schultz Pass (U.S. Forest Service Road 420, $2.4 \mathrm{~km}$ away from I-89 highway), north of Flagstaff , Arizona , USA, at an altitude of 2.400 meters in 1988. This area is characterized as a xeric environment with completely preserved vegetation and is located within the Coconino

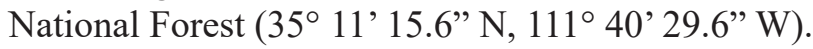

Chrysothamnus nauseosus subsp. hololeucus (Asteraceae), from now on just C. nauseosus (Fig. 1a), is a morphologically diverse and abundant shrub species in the study area, distributed from southwestern Canada to northern Mexico (Anderson 1966; Toft $\&$ Fraizer 2003). This species is erect, thin and flexible with branches covered by a dense layer of white or greenish-gray trichomes. It has narrow leaves and it flowers late in summer (Anderson 1966). Chrysothamnus nauseosus is a host of a large number of galling insects (Floate et al. 1996; Fernandes et al. 2000b). This study focused on galls induced by Rhopalomyia chrysothamni (Cecidomyiidae: Diptera). The stem galls are conical in shape, a light green color, and with bunched white short trichomes (Fig. 1b) (Gagné 1989; Fernandes et al. 2001).

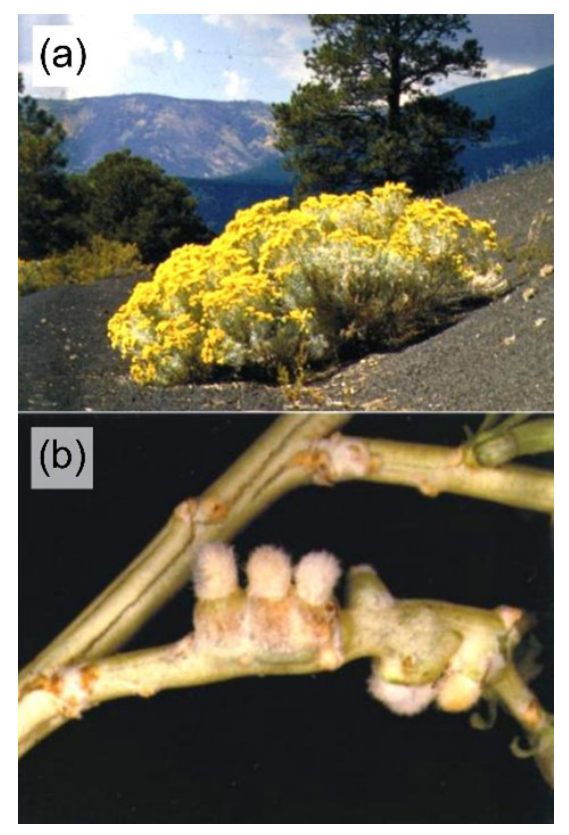

Figure 1. Studied host plant - galling insect system. a) Host plant Chrysothamnus nauseosus subsp. hololeucus (Asteraceae) in Schultz Pass, Arizona, USA. b) Stem galls induced by Rhopalomyia chrysothamni (Diptera: Cecidomyiidae).

\section{Preparation of the Experiment}

Sixty individuals of $C$. nauseosus were randomly marked in the field and randomly divided into three groups of 20 individuals per group. Before the experimental intervention, all branches containing stem 
galls of $R$. chrysothamni or any other types of galls were removed with the aid of pruning clippers. After this thinning of galled branches, the selected individuals had similar heights and numbers of branches. Each treatment group of plants was submitted to a nutrient and/or water application. The control treatment consisted of individuals that received neither irrigation nor fertilization, representing the xeric condition of the natural environment. Plants in the irrigated treatment received $3.8 \mathrm{~L}$ of water per week, while plants in the fertilized treatment (fertilizer + water) received $13 \mathrm{~g}$ of NPK (20:20:20) applied weekly diluted in $3.8 \mathrm{~L}$ of water. These treatments simulated mesic environmental conditions considering that the soils had better water (irrigated) or hydric-nutritional (fertilizer + water) quality (see Fernandes \& Price 1991). Fertilization and irrigation were conducted during the year 1988 from April 1 to September 15, which is approximately the growing season in the region. The irrigation process was equivalent to an increase of $129.6 \mathrm{~mm}$ of monthly rainfall, totaling an increase of $777.6 \mathrm{~mm}$ in annual precipitation.

\section{Evaluation of the female galling insect attack}

At the end of growing season (October / November) the number of attacked plants was recorded. All galls induced by $R$. chrysothamni found on the host plants were collected, placed in labeled plastic bags (one per individual) and brought to the laboratory where they were frozen for later analysis. All galls were thawed, had their diameter measured with a digital caliper ( $0.01 \mathrm{~mm}$ precision) for determination of basal area (considering the circular shape). After this stage the galls were separated from the stem with the aid of a dissecting needle and stereo microscope and their dry mass was measured with an analytical balance (precision $0.1 \mathrm{mg}$ ) after drying at $70^{\circ} \mathrm{C}$ to constant weight. A gall density index was calculated, which corresponded to the ratio between dry mass and gall basal area (mg. $\left.\mathrm{mm}^{-2}\right)$. In total 35 plant individuals that had 698 galls (537 living galls) were sampled. To calculate the abundance, basal area and dry mass of galls only galls with live larva were considered.

\section{Statistical analyses}

Each plant individual ( $\mathrm{n}=10$ to 15 individuals per treatment) was considered as a sampling unit in the analysis, according to the number of plants attacked in each treatment. To evaluate the effect of irrigation and fertilization on gall size of $R$. chrys- othamni, the Kruskal-Wallis test followed by multiple comparisons between treatments $(\alpha=0.05$; Zar 1996) was used.

\section{RESULTS}

The infestation of galls induced by $R$. chrysothamni was lower on irrigated and fertilized plant individuals. The rate of gall infestation in the more xeric treatment (i.e. control plants) was $75 \%$ (15 out of the 20 individuals), while only $50 \%$ of irrigated and fertilized plants (both; ten out of the 20 individuals) contained galls (Fig. 2a). On the other hand, the abundance of galls per plant was not significantly different among the treatments $(\mathrm{p}>0.05)$, although there was a slight trend towards greater abundance of galls on plants in the irrigated and fertilized treatments (Fig. 2b).
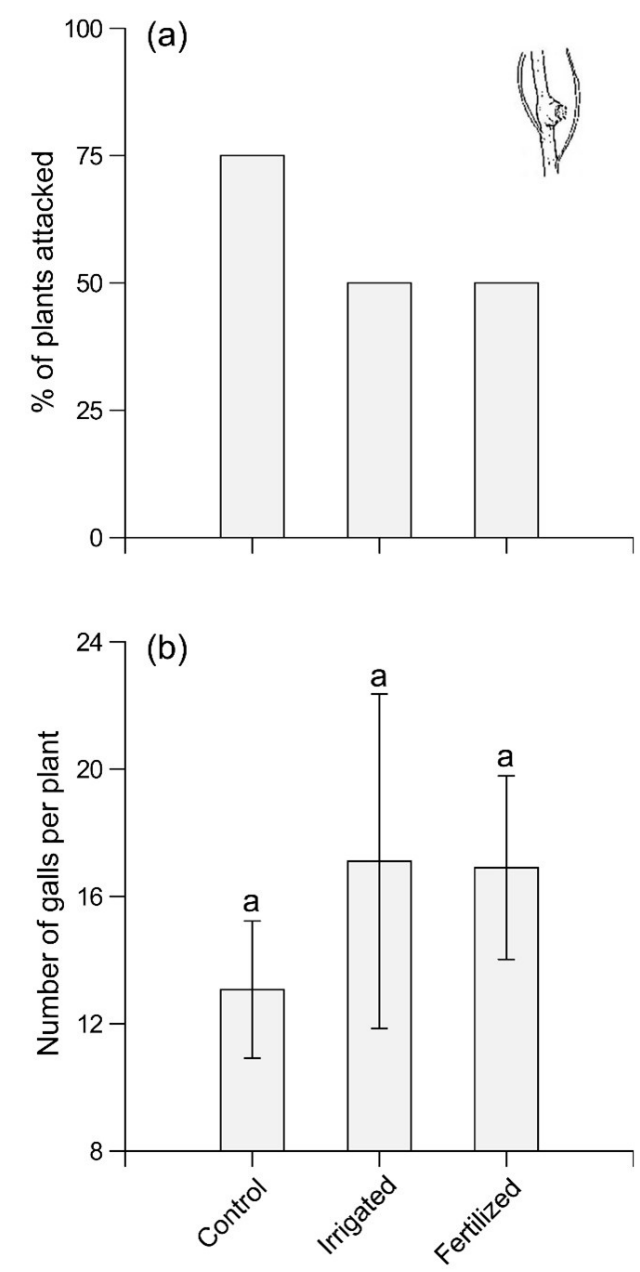

Figure 2. Effect of the host plant quality on $\%$ of plants attacked and number of galls per plant. a) $\%$ of host plants attacked by Rhopalomyia chrysothamni gall $(\mathrm{n}=20$ plants per treatment); b) Number of $R$. chrysothamni galls per individual of Chrysothamnus nauseosus. 
Regarding to the growth of $R$. chrysothamni galls, fertilized plants had galls with higher dry mass compared to galls on control and irrigated plants (38\% more tissue biomass; $p<0.05$; Fig $3 a)$. The average total biomass of galls per plant was $262.8 \mathrm{mg}$ for control treatment, $367.4 \mathrm{mg}$ for irrigated treatment, and $453.2 \mathrm{mg}$ for fertilizer + water treatment. The gall density index on the fertilized plants was also $21 \%$ higher than on the control plants, and $31 \%$ greater than on the irrigated plants ( $<<0.05$; Fig. $3 b)$. On the other hand, the basal area of the galls was not significantly different among the treatments $(\mathrm{p}>0.05$; Fig. 3c).

\section{DiscuSSION}

The differences in habitat quality simulated by fertilizer and water treatments influenced both the number of galls per plant plant and the growth of the $R$. chrysothamni galls on $C$. nauseosus. The highest number of infected plants was found in the control treatment which represented the more xeric habitat condition that prevailed in the study area, hence supporting the hypothesis of water and nutritional stress that predicts a larger infestation rate by gall-inducing insects on plants under stressed or xeric environments. These results are similar to those found by Fernandes and Price (1992) analyzing different communities of galling insects in C. nauseosus in the southwest of the USA. The authors reported higher populations of 6 species of galling insects and larger number of attacked plants in xeric environments as opposed to mesic. On the other hand, Cuevas-Reyes et al. (2011) using nitrogen and phosphorus as indicators of soil fertility in populations of Eremanthus glomerulatus (Asteraceae) reported idiosyncratic patterns in the rate of galling insect infestation, depending on the species of Cecidomyiidae.

The present study did not corroborate the hypothesis of a greater abundance of galls on plants under more intense environmental stress. This result contradicts the trend observed in other studies that have shown that hosts in more stressed habitats (both in tropical and in temperate environments) harbor a greater abundance of galls (Fernandes \& Price 1992; Ribeiro-Mendes et al. 2002; Jesus et al. 2012; Fagundes et al. 2020). Due to the fact that we were able to conduct such experiment only during one growing season, we argue that perhaps the time was not long enough to obtain a numerical response of the population by the galling species. While long-term study would likely represent an ideal scenario to test such
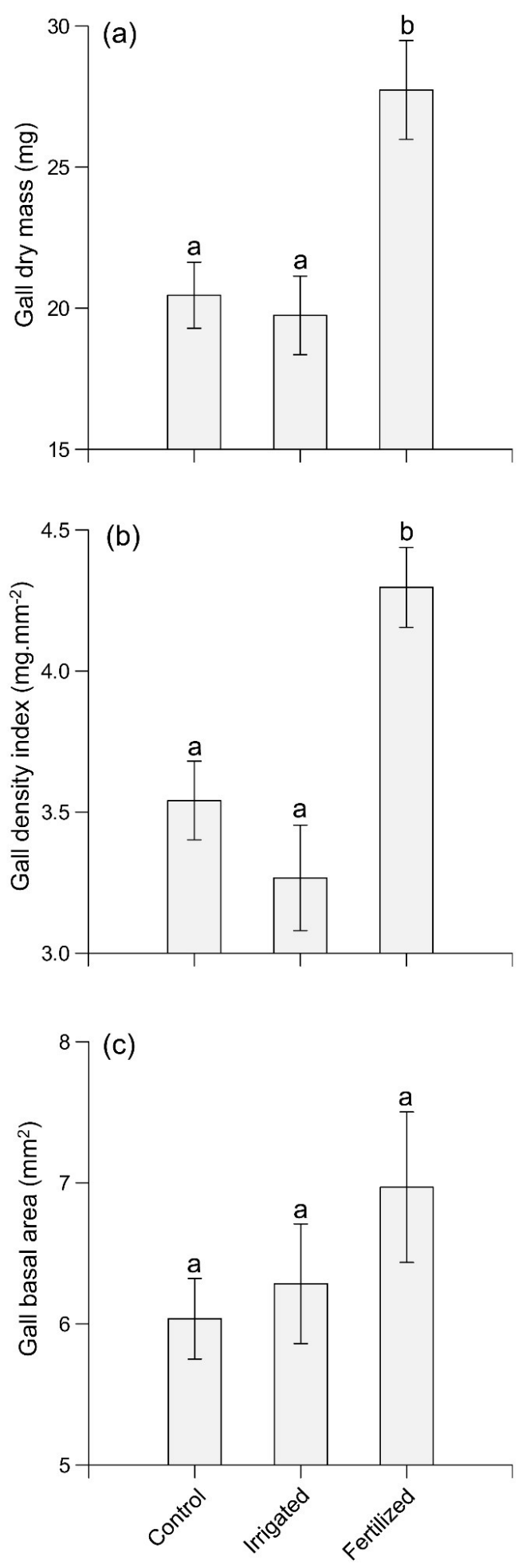

Figure 3. Effect of the host plant quality on the development performance of galls. a) Average gall dry mass (mg); b) Average gall density index (ratio of dry mass per basal area of each gall; mg.mm ${ }^{-2}$ ); c) Average gall basal area (considering the cylindrical shape; $\mathrm{mm}^{2}$ ). 
hypotheses, the chances of conducting studies in the field would require different logistical arrangements.

Regarding gall growth, only in the situation where both water and nutritional stresses were relieved (fertilizer + water treatment) plants developed galls with greater dry mass. The fact that increased availability of water resulted in no increase in dry mass, density and size of galls, may suggest that the main factor of environmental stress on the system Chrysothamnus - Rhopalomyia is related to soil fertility. Rossi and Stiling (1998) showed that plants subjected to nitrogen fertilization harbored galls with a diameter $17.3 \%$ larger than the galls on plants in the control treatment. However, Fernandes et al. (2000a) analyzing the effect of NPK availability on galls induced by Aciurina trixa (Tephritidae) in the same population as in the current study of $C$. nauseosus found no significant differences between the diameter of galls on plants in fertilized and control treatments.

The results obtained in this study point to a paradox: although females of galling insects preferentially selected more stressed plants (i.e. less water and nutritional quality), Rhopalomyia galls that develop on less stressed plants reached a higher biomass, (which may theoretically results in larger larvae and fitter adults) (Abrahamson \& Weis 1987; Weis et al. 1988; Santos et al. 2007). In other words, although females of galling insects preferentially select more xeric environments, the development of the galls was better in relatively more mesic environments. The results of the current study indicated that there is a trade-off between quantity and quality of galls of $R$. chrysothamni and that it is influenced by the nutritional quality of the host plant. Future studies related to mortality factors and performance of larval and adult stages of galling insects in the long term may help in better understanding of the mechanisms involved.

\section{ACKNOWLEDGMENTS}

We thank A. A. Efremova for her comments on earlier versions of the manuscript, Conselho Nacional de Desenvolvimento Científico e Tecnológico (CNPq), Fundação de Amparo à Pesquisa do Estado de Minas Gerais (FAPEMIG), Coordenação de Aperfeiçoamento de Pessoal de Nível Superior (CAPES) for financial supports.

\section{REFERENCES}

Abrahamson, W.G. \& Weis, A.E. (1987) Nutritional ecology of arthropod gall makers. In: F. Slansky \& J.G. Rodriquez (Eds.), Nutritional ecology of insects, mites, spiders, and related invertebrates (pp. 235-258). New York: Wiley.

Anderson, L.C. (1966) Cytotaxonomic studies in Chrysothamnus (Asteraceae, Compositae). American Journal of Botany, 53, 204-212. DOI: https:/doi.org/10.1002/J.1537-2197.1966. TB07323.X

Araújo, A.P., Carneiro, M.A.A. \& Fernandes, G.W. (2003) Effects of gender, vigor and size of the host plant Baccharis pseudomyriocephala Teodoro (Asteraceae) on gall-inducing insect distribution. Revista Brasileira de Entomologia, 47, 483-490. DOI: https://doi.org/10.1590/S008556262003000400001

Blanche, K.R. \& Westoby, M. (1995) Gall-forming insect diversity is linked to soil fertility via host plant taxon. Ecology, 76, 2334-2339. DOI: https://doi.org/10.2307/1941706

Carneiro, M.A.A., Branco, C.S.A., Braga, C.E.D., Almada, E.D., Costa, M., Maia, V.C., et al. (2009) Are gall midge species (Diptera: Cecidomyiidae) host plant specialists? Revista Brasileira de Entomologia, 53, 365-378. DOI: https:// doi.org/10.1590/S0085-56262009000300010

Cornelissen, T.G., Fernandes, G.W. \& Vasconcellos, J. (2008) Size does matter: variation in herbivory between and within plants and the plant vigor hypothesis. Oikos, 117, 1121-1130. DOI: https:// doi.org/10.1111/j.2008.0030-1299.16588.x

Cuevas-Reyes, P., Quesada, M., Siebe, C. \& Oyama, K. (2004) Spatial patterns of herbivory by gall-forming insects: a test to the soil fertility hypothesis in a Mexican tropical dry forest. Oikos, 107, 181-189. DOI: https://doi.org/10.1111/ j.0030-1299.2004.13263.x

Cuevas-Reyes, P., Oliveira-Ker, F.T., Fernandes, G.W. \& Bustamante, M. (2011) Abundance of gall-inducing insect species in sclerophyllous savanna: understanding the importance of soil fertility using an experimental approach. Journal of Tropical Ecology, 27, 631-640. DOI: https://doi. org/10.1017/S0266467411000368

Fagundes, M., Faria, M.L. \& Fernandes, G.W. (2001) Effects of the distribution of Baccharis dracunculifolia (Asteraceae) in the abundance and parasitism of Neopelma baccharidis (Homoptera: Psyllidae) structure. Unimontes Científica, 1, 97-103. 
Fagundes, M., Cuevas-Reyes, P., Leite, L.F.R., Borges, M.A.Z., Araújo, W.S., Fernandes, G.W., et al. (2020) Diversity of gall-inducing insects associated with a widely distributed tropical tree species: testing the environmental stress hypothesis. Environmental Entomology, 49, 838-847. DOI: https://doi.org/10.1093/ee/nvaa072

Fay, P.A., Hartnett, D.C. \& Knapp, A.K. (1996) Plant tolerance of gall-insect attack and gall insect performance. Ecology, 77, 521-534. DOI: https:// doi.org/10.2307/2265627

Fernandes, G.W. \& Price, P.W. (1988) Biogeographical gradients in galling species richness: tests of hypotheses. Oecologia, 76, 161-167. DOI: https://doi.org/10.1007/BF00379948

Fernandes, G.W. \& Price, P.W. (1991) Comparison of tropical and temperate galling species richness: the roles of environmental harshness and plant nutrient status. In: P.W. Price, T.M. Lewinsohn, G.W. Fernandes \& W.W. Benson (Eds.), Plant-animal interactions: evolutionary ecology in tropical and temperate regions (pp. 91-115). New York, John Wiley.

Fernandes, G.W. \& Price, P.W. (1992) The adaptive significance of insect gall distribution: survivorship of species in xeric and mesic habitats. Oecologia, 90, 14-20. DOI: https://doi.org/10.1007/ BF00317803

Fernandes, G.W. \& Carneiro, M.A.A. (2009) Insetos galhadores. In: A.R. Panizzi \& J.R.P. Parra (Eds.), Bioecologia e nutrição de insetos - base para o manejo integrado de pragas (pp. 595-636). Brasília, EMBRAPA Soja.

Fernandes, G.W., Lara, A.C.F. \& Price, P.W. (1994) The geography of galling insects and the mechanisms that result in patterns. In: P.W. Price, W.J. Mattson \& Y.N. Baranchikov (Eds.), The ecology and evolution of gall-forming insects (pp. 42-48). St Paul, USDA.

Fernandes, G.W., Castro, F.M.C. \& Marques, E.S.A. (1999) Leaflet abscission caused by a gall induced by Melaphis rhois (Homoptera: Aphididae) on Rhus glabra (Anacardiaceae). International Journal of Ecology and Environmental Sciences, 25, 63-69.

Fernandes, G.W., Price, P.W., Gonçalves-Alvim, S.J., Craig, T.P. \& Yanega, D. (2000a) Response of the galling insect Aciurina trixa Curran (Diptera: Tephritidae) to host plant quality. Anais da Sociedade Entomológica do Brasil, 29, 423-431. DOI: http://dx.doi.org/10.1590/S030180592000000300005
Fernandes, G.W., Saraiva, C., Cornelissen, T.G. \& Price, P.W. (2000b) Diversity and morphology of insect galls on Chrysothamnus nauseosus (Asteraceae) in Northern Arizona. BIOS, 8, 39-48.

Fernandes, G.W., Saraiva, C., Soares, G.A., Negreiros, D., Duarte, M. \& Price, P.W. (2001) Some insect galls of Arizona. Naturalia, 26, 191-209.

Fernandes, G.W., Santos, J.C. \& Gomes, V.M. (2012) Misleading herbivory in a tropical tree. Arthropod-Plant Interactions, 6, 649-654. DOI: https://doi.org/10.1007/s11829-012-9212-5

Floate, K.D., Fernandes, G.W. \& Nilsson, J. (1996) Distinguishing intrapopulational categories of plants by their insect faunas: galls on rabbitbrush. Oecologia, 105, 221-229. DOI: https:// doi.org/10.1007/BF00328550

Fonseca, C.R. \& Fleck, T. (2007) Hypotheses for the richness of gall insects: a review considering the intraespecific, interespecific and community levels. Neotropical Biology and Conservation, 2, 36-45.

Gagné, R.J. (1989) The plant-feeding gall midges of North America. Ithaca, Cornell University Press.

Gonçalves-Alvim, S.J. \& Fernandes GW (2001) Biodiversity of galling insects: historical, community and habitat effects in four neotropical savannas. Biodiversity and Conservation, 10, 79-98. DOI: https://doi.org/10.1023/A:1016602213305

Gonçalves-Alvim, S.J., Landau, E.C., Fagundes, M., Silva, V.G., Nunes, Y.R.F. \& Fernandes, G.W. (1999) Abundance and impact of a lepidopteran gall on Macairea radula (Melastomataceae) in the Neotropics. International Journal of Ecology and Environmental Sciences, 25, 115-125.

Gonçalves-Alvim, S.J., Santos, M.C.F.V. \& Fernandes, G.W. (2001) Leaf gall abundance on Avicennia germinans (Avicenniaceae) along an interstitial salinity gradient. Biotropica, 33, 69-77. DOI: https://doi.org/10.1111/j.1744-7429.2001. tb00158.x

Hall, C.R., Carroll, A.R. \& Kitching, R.L. (2017) A meta-analysis of the effects of galling insects on host plant secondary metabolites. Arthropod-Plant Interactions, 11, 463-473. DOI: https://doi.org/10.1007/s11829-016-9486-0

Jesus, F.M., Silva, J.O., Fagundes, M. \& Fernandes, G.W. (2012) Differential female attack and larval performance of a galling cecidomyiid on the host, Astronium fraxinifolium (Anacardiaceae), in contrasting habitats. Entomological News, 122, 10 21. DOI: https://doi.org/10.3157/021.122.0102 
Kirst, G.O. \& Rapp, H. (1974) Zur physiologie der Galle von Mikiola fagi Htg. auf Blattern von Fagus silvatica L. II. Transport ${ }^{14} \mathrm{C}$ markierter Assimilate aus dembefallenen Blatt und aus Nachbarblattern in die Galle. Biochemistry and Physiology Pflanz, 165, 445-455. DOI: https:// doi.org/10.1016/S0015-3796(17)30992-7

Larson, K.C. \& Whitham, T.G. (1991) Manipulation of food resources by a gall-forming aphid: the physiology of sink-source interactions. Oecologia, 88, 15-21. DOI: https://doi.org/10.1007/ BF00328398

Mani, M.S. (1964) Ecology of plant galls. The Hague, Dr. W. Junk.

Miller, D.G. III \& Raman, A. (2019) Host-plant relations of gall-inducing insects. Annals of the Entomological Society of America, 112, 1-19.

Mithöfer, A. \& Boland, W. (2012) Plant defense against herbivores: chemical aspects. Annual Review of Plant Biology, 63, 431-450. DOI: https://doi.org/10.1093/aesa/say034

Price, P.W., Waring, G.L. \& Fernandes, G.W. (1986) Hypotheses on the adaptive nature of galls. Proceedings of the Entomological Society of Washington, 88, 361-363.

Price, P.W., Fernandes, G.W. \& Waring, G.L. (1987) Adaptive nature of insect galls. Environmental Entomology, 16, 15-24. DOI: https://doi. org/10.1093/ee/16.1.15

Price, P.W., Coob, N., Craig, T.P., Fernandes, G.W., Itami, J.K., Mopper, S., et al. (1990) Insect herbivore population dynamics on trees and shrubs: new approaches relevant to latent and eruptive species and life table development. In: E.A. Bemays (Ed.), Insect-plant interactions (pp. 1-38). Boca Raton, CRC Press.

Price, P.W., Fernandes, G.W., Lara, A.C.F., Brawn, J., Barrios, H., Wright, M.G., et al. (1998) Global patterns in local number of insect galling species. Journal of Biogeography, 25, 581-592. DOI: https://doi.org/10.1046/j.13652699.1998.2530581.x

Ribeiro-Mendes, H., Fernandes, G.W. \& Silva, I.M. (2002) Influence of host-plant sex and habitat on survivorship of insects galls within the geographical range of the host-plant. Tropical Zoology, 15, 5-15. DOI: https://doi.org/10.1080/039 46975.2002.10531163
Rossi, M.A. \& Stiling, P. (1998) The interactions of plant clone and abiotic factors on a gall-making midge. Oecologia, 116, 170-176. DOI: https:// doi.org/10.1007/s004420050576

Santos, J.C., Silveira, F.A.O. \& Fernandes, G.W. (2007) Long term oviposition preference and larval performance of Schizomyia macrocapillata (Diptera Cecidomyiidae) on larger shoots of its host plant Bauhinia brevipes (Fabaceae). Evolutionary Ecology, 22, 123-137. DOI: https://doi. org/10.1007/s10682-007-9162-z

Silva, I.M., Andrade, G.I., Fernandes, G.W. \& Lemos-Filho, J.P. (1996) Parasitic relationships between a gall forming insect Tomoplagia rudolphi (Diptera: Tephritidae) and its host plant (Vernonia polyanthes, Asteraceae). Annals of Botany, 78, 45-48. DOI: https://doi.org/10.1006/ anbo. 1996.0093

Toft, C.A. \& Fraizer, T. (2003) Spatial dispersion and density dependence in a perennial desert shrub (Chrysothamnus nauseosus: Asteraceae). Ecological Monographs, 73, 605-624. DOI: https:// doi.org/10.1890/02-4080

Tooker, J.F. \& Helms, A.M. (2014) Phytohormone dynamics associated with gall insects, and their potential role in the evolution of the gall-inducing habit. Journal of Chemical Ecology, 40, 742-753. DOI: https://doi.org/10.1007/s10886014-0457-6

Weis, A.E., Walton, R. \& Crego, L.C. (1988) Reactive plant tissues sites and the population biology of gall makers. Annual Review of Entomology, 33, 467-486. DOI: https://doi.org/10.1146/annurev.en.33.010188.002343

Xiang, Y., Guo, W., Shen, S., Gao, X. \& Li, X. (2020) Galling impacts of the gall wasp Leptocybe invasa (Hymenoptera: Eulophidae) on Eucalyptus trees vary with plant genotype. International Journal of Tropical Insect Science, 40, 267-275. DOI: https://doi.org/10.1007/s42690019-00076-9

Zar, J.H. (1996) Biostatistical analysis (3rd Ed.). Englewood Cliffs, Prentice-Hall. 